\title{
Kajian Fiqih Berbasis Margin Murabahah Dan Kaitannya Dengan Risiko Reputasi
}

\author{
Nasrul Amanu ${ }^{(*)}$, Jafril Khalii ${ }^{2}$, Koesmawan ${ }^{3)}$, Amrizal $^{4)}$, Saiful Anwar ${ }^{5}$ \\ ${ }^{1}$ Program Pascasarjana Magister Keuangan Syariah, Institut Teknologi dan Bisnis Ahmad Dahlan, Jakarta \\ 2,3,4,5 Dosen Program Pascasarjana Magister Keuangan Syariah, Institut Teknologi dan Bisnis Ahmad Dahlan Jakarta \\ *Email korespondensi: nasrulamanu.an@gmail.com
}

\begin{abstract}
This study aims to determine how much the impact of reputation risk on Islamic Banks in BPRS Patriot Bekasi, to analyze the implementation of Murabahah in BPRS Patriot Bekasi and to find solutions in implementing Murabahah which is considered imperfect which can lead to reputation risk at BPRS Patriot Bekasi. The method used is through qualitative research by means of observation and distributing questionnaires to respondents in the customers of the Patriot Bekasi Islamic People's Financing Bank (BPRS). From these results, there were 22 respondents or $72.6 \%$ of 30 respondents stated that the risk impact was very large on BPRS Patriot Bekasi, while 8 respondents or $27.4 \%$ of the 30 respondents sampled stated no, that the risk impact was very large on BPRS. Patriot Bekasi. There are 30 respondents or $100 \%$ of the 30 respondents said yes, that the Patriot Bekasi Islamic Rural Bank (BPRS) has conducted an analysis of the implementation of the Murabahah contract according to the condition of the community or the customer, so that it is expected that there will be no default or default. There were 29 respondents or $96.7 \%$ of 30 respondents said yes, that the Patriot Bekasi Islamic Rural Bank (BPRS) has been looking for a solution in implementing Murabahah which is considered imperfect which could lead to reputational risk to customers.
\end{abstract}

Keywords: Murabahah, reputation risk, BPRS PATRIOT BEKASI

Saran sitasi: Amanu, N., Khalil, J., Koesmawan., Amrizal., \& Anwar, S. (2021). Kajian Fiqih Berbasis Margin Murabahah Dan Kaitannya Dengan Risiko Reputasi. Jurnal Ilmiah Ekonomi Islam, 7(01), 501-512. doi:http://dx.doi.org/10.29040/jiei.v7i1.1558

DOI: http://dx.doi.org/10.29040/jiei.v7i1.1558

\section{PENDAHULUAN}

Masa depan Perbankan sangat ditentukan oleh kemampuan management perbankan islam dan menghadapi berbagai perubahan pesat yang terjadi saat ini. Pesatnya informasi dan teknologi serta inovasi keuangan membuat sektor keuangan tempat perbankan islam bernaung semakin menjadi kompleks dinamis dan kompetitif. Kondisi itu berpotensi meningkatkatnya risiko terhadap perbankan islam di mana semua risiko ini mutlak harus dikelola. Bank Islam harus lebih memulai mengelola risiko tersebut seperti risiko reputasi contohnya. Risiko reputasi itu akibat menurunnya kepercayaan stakeholder yang bersumber dari persepsi negatif terhadap Bank dampak kejadian reputasi pada umumnya menyebabkan kerugian non finansial bagi Bank. Risiko reputasi terjadi akibat kejadian-kejadian yang merugikan reputasi Bank Syariah misalnya pemberitaan negatif di media massa, pelanggaran etika, dan keluhan nasabah yang bisa menyebabkan risiko repuitasi. (Fauziah, 2019)

Perbankan Syariah adalah segala sesuatu yang menyangkut tentang Bank Syariah dan Unit Usaha Syariah, mencakup kelembagaan, kegiatan usaha, serta cara dan proses dalam melaksanakan kegiatan usahanya (Pasal 1 UU No.21Tahun 2008 tentang Perbankan Syariah). Dengan definisi itu berarti perbankan Syariah meliputi Bank Umum Syariah (BUS), Unit Usaha Syariah (UUS), dan Bank Pembiayaan Rakyat Syariah (BPRS). (Hasan, 2009)

Menurut (S. Kasmir, 2014), negative spread terjadi apabila suku bunga simpanan lebih besar dari suku bunga kredit. Krisis ini telah membawa dampak yang sangat buruk bagi lembaga perbankan Indonesia, karena beberapa Bank tidak dapat bertahan dan akhirnya dilikuidasi. Inilah yang menyebabkan kepercayaan masyarakat terhadap lembaga perbankan menjadi menurun. 
Sedangkan dalam perbankan syariah hanya mengenal sistem kepercayaan, keuntungan didapat karena ada kesepakatan, yang dimaksud sepakat disini adalah nasabah menyadari risiko dan manfaat dari pelayanan perbankan syariah, kemudian margin yang akan diterima oleh bank harus disepakati bersama. Islam mengajarkan tolong menolong bagi sesama umat manusia, ketika mencari keuntungan terhadap seseorang yang sedang membutuhkan pertolongan maka hukumnya dilarang, namun dengan pemberlakuan sistem kepercayaan, dinilai memiliki risiko besar, karena dasar kepercayaan sangatlah abstrak mungkin tidak masuk akal.

Dengan lemahnya sosialisasi ditambah dengan beragam anggapan miring yang berkembang cukup masih menjadikan keberadaan dan kesyariahan Bank Syariah masih diragsukan oleh sebagian masyarakat. Bank syariah memiliki risiko yang lebih kompleks dibandingkan dengan perusahaan yang bergerak di sektor lainnya. Kompleksitas persoalan perbankan tidak semata menyangkut organ-organ perusahaan tetapi juga melibatkan nasabah dan masyarakat luas serta kondisi stabilitas perekonomian dalam cakupan yang lebih luas. Risiko dan pelaksanaan management risiko pada perbankan syariah lebih rumit. Dianggap lebih rumit setidaknya disebabkan dua hal, pertama bank syariah menghadapi risiko. Sebagaimana risiko yang biasa dihadapi oleh bank konvensional seperti risiko oleh kredit, risiko pasar, risiko reputasi, risiko likuiditas dan risiko operasional. Kedua risiko-risiko yang disebutkan di atas akan menghadapi kondisi yang berbeda ketika berhadapan dengan kewajiban mematuhi prinsip-prinsip syariah. (Fauziah, 2019)

Kinerja pertumbuhan pendapatan PT. Bank Pembiayaan Rakyat Syariah (BPRS) Patriot Bekasi terbukti terus mengalami peningkatan dari tahun ke tahun, pada tahun 2018 dengan kinerja pembiayaan yang baik meskipun pendapatan di tahun 2018 mengalami defisit sebesar Rp. 4.577.216.417.- atau 15,97\%, akan tetapi pada tahun 2019 mengalami pendapatan yang meningkat yaitu sebesar Rp. 1.200.474.326, - atau 4,30\%. (BPRS, 2018)

Menurut Direktur BPRS Patriot Bekasi Mohammad Asmawi, peningkatan asset mencapai $25 \%$, Signifikannya peningkatan tersebut didorong oleh semakin tingginya kepercayaan masyarakat. Asset perseroan tumbuh sebesar $21,06 \%$ atau senilai Rp. 26,9 milyar dibandingkan periode yang sama pada 2019 yakni sebesar Rp. 23,6 milyar ada lonjakan untuk tabungan, deposito dan pembiayaan. (BPRS, 2018).

\section{Tabel 1}

Pembiayaan Murabahah Bank Pembiayaan Rakyat Syariah (BPRS) Patriot Bekasi Tahun 2018-2019

\begin{tabular}{|c|c|c|}
\hline $\begin{array}{c}\text { Pembiayaan } \\
\text { Murabahah }\end{array}$ & $\mathbf{2 0 1 8}$ & $\mathbf{2 0 1 9}$ \\
\hline Murabahah & 13.973 .278 .821 & 15.730 .496 .020 \\
\hline
\end{tabular}

Sumber: Data olahan keuangan BPRS Patriot Kota

Bekasi (Dalam jurnal lukman haryoso: vol. 2, no. 1)

Banyak isu bermunculan mengenai keberadaan lembaga keuangan syari'ah ini. Diantaranya adalah dari tiga jenis pembiayaan yang menjadi produk utama lembaga keuangan syariah yaitu pembiayaan mudharobah, pembiayaan musyarakah, dan pembiayaan murabahah, yang paling mendominasi yaitu pembiayaan murabahah. Pembiayaan dengan akad murabahah mencapai $56,8 \%$ dari total pembiayaan lain yang ada di perbankan syariah, sedangkan pembiayaan mudharabah dan musyarakah hanya $22,1 \%$ dan $14,1 \%$ dari total pembiayaan yang ada.

Melihat hasil penelitian dalam jurnal yang ditulis oleh Amilis Kina, menemukan fakta yang dialami BMT Pare. Berikut ini adalah salah satu contoh dari pembiayaan Murabahah bermasalah yang terjadi pada BMT Pare disajikan data NPL yang mengaplikasikan pembiayaan murabahah bermasalah sebagai berikut.

Tabel. 1.2

Data kolektibilitas (dalam bentuk Persentase)

\begin{tabular}{|c|c|c|c|c|}
\hline No. & Lancar & Kurang Lancar & Diragukan & Macet \\
\hline 1. & 87,47 & 3,55 & 8,98 & 0 \\
\hline 2. & 73,50 & 2,84 & 23,66 & 0 \\
\hline 3. & 76,35 & 2,47 & 18,10 & 0,08 \\
\hline
\end{tabular}

Sumber: Data Intern BMT Syari'ah Pare (2008)

Dari data di atas bahwa $87,47 \%$ banyaknya nasabah yang lancar dalam pembiayaannya, namun tidak diragukan lagi bahwa 3,55\% nasabah yang mengalami kurang lancar dalam pembayayarnya. Bahkan mengalami gagal bayar sebesar $0,08 \%$ pun ada dari nasabah tersebut. Ini merupakan tugas dari karyawan perbankan syariah untuk mencari tahu apa penyebab dari gagal bayar tersebut. Apakah karena nasabah berhenti bekerja (PHK) atau lainnya. Ini merupakan taanggung jawab yang harus dicarikan solusinya, sehingga tidak akan terulang kembali dikemudian hari.

Berbeda halnya dengan pembiayaan Murabahah mempunyai pengaruh positif terhadap pendapatan 


\section{Jurnal Ilmiah Ekonomi Islam, 7(01), 2021, 503}

BPRS Patriot Bekasi. Pembiayaan Murabahah BPRS Patriot Kota Bekasi pada 2019 mencapai Rp.13.973.278.821, - meningkat dibandingkan pembiayaan 2018 mencapai Rp. 13.973.278.821, -. (BPRS, 2018) Pembiayaan BPRS Patriot Bekasi mencapai 29,7 milyar atau meningkat hingga $62 \%$ dibandingkan pembiayaan ditahun 2019 yakni 18,3 milyar. (BPRS, 2018)

Margin adalah presentase tertentu yang ditetapkan perbulan atau pertahun, perhitungan margin keuntungan yaitu suatu istilah yang dipergunakan dalam dunia untuk menunjukkan suatu yang wajib ditempatkan oleh pemegang suatu posisi dalam perdagangan, atau guna melindungi begitu juga dengan lembaga keuangan Syariah, dalam menjalankan bisnis dan usahanya juga tidak terlepas dari sistem Syariah. Margin merupakan selisih antara harga beli dan harga jual, yang merupakan keuntungan kotor dalam transaksi jual beli barang. Margin tidak sama dengan bunga karena margin harus sudah ditentukan pada awal dalam perjanjian dan tidak dapat berubah di tengah jalan. (Ahmad Ghozali, 2005).

Teori margin pada lembaga keuangan Syariah, margin adalah presentase tertentu yang ditetapkan perbulan atau pertahun di awal akad berdasarkan prinsip jual beli (Murabahah) dan berdasarkan kesepakatan bersama antara lembaga keuangan Syariah dan anggota. Berdasarkan survey yang peneliti lakukan kepada nasabah yang menggunakan jasa pembiayaan di Bank Pembiayaan Rakyat Syariah (BPRS) Patriot Kota Bekasi berdasarkan dari keterangan nasabah DinaWulandari, dijelaskan bahwa, margin di Bank Pembiayaan Rakyat Syariah (BPRS) Patriot Kota Bekasi sudah sesuai dengan teori, yaitu presentasi margin ditentukan di awal akad berdasarkan kesepakatan antara pihak Lembaga Keuangan Syariah (LKS) dan anggota, serta berdasarkan jual-beli (Murabahah) dan besarnya angsuran tidak dapat berubah di tengah jalan. (Wawancara Anton, Desember 2019 sampai dengan Januari 2020).

Mengutamakan cara dan proses yang benar dalam meraih keuntungan merupakan aspek penting dalam kebijakan pengambilan keuntungan yang selaras dengan prinsip Syariah. Dalam Bank Syariah tidak dikenal istilah bunga dalam memberikan jasa kepada penyimpan maupun peminjam. Untuk menghindari penerimaan dan pembayaran bunga (riba), maka perbankan Syariah menempuh salah satu cara yaitu dengan memberikan pembiasaan berdasarkan jual beli dengan menggunakan akad Murabahah.

Sistem pembiayaan di murabahah berbeda dengan sistem yang ada dalam skema kredit pada perbankan konvensional. Biasanya margin dinyatakan sebagai persentase yang harus diterapkan pada semua biaya yang dikeluarkan oleh Bank di dalam memenuhi murabahah. Sistem pembiayaan di murabahah berbeda dengan sistem yang ada dalam skema kredit pada perbankan konvensional. Jika di Bank Konvensional sistem bunga kredit bisa fluktuatif sesuai dengan keadaan pasar, suku bunga, dan kondisi makro ekonomi, maka di Bank Syariah margin yang ditetapkan pada saat penandatanganan akad pembiayaan tidak boleh berubah meskipun terjadi inflasi, ataupun kenaikan tingkat suku bunga pasar.

Akad murabahah merupakan akad yang paling dominan disalurkan oleh Bank Syariah dibanding dengan akad pembiayaan lainnya. Dari sejak awal tahun 1984, di Pakistan, pembiayaan murabahah bisa mencapai sekitar delapan puluh tujuh persen $(87 \%)$ dari keseluruhan pembiayaan dalam investasi deposito profit and loss sharing (Lubis, 2016). Banyak Bank Syariah begitu atraktif menawarkan produk pembiayaan komersial lewat pola jual beli (murabahah), salah satunya adalah PT. Bank Syariah X Cabang Pontianak. Dengan skema murabahah, Bank Syariah X membiayai kebutuhan nasabah dalam hal pengadaan barang konsumsiseperti rumah, kendaraan atau barang produktif. Dari penyaluran dana tersebut, Bank memperoleh pendapatan berupa margin. Margin yang dimaksud di sini merupakan tingkat keuntungan yang diharapkan oleh Bank Syariah yang dinyatakan dalam bentuk nominal atau persentase tertentu (Jurnal Ekonomi, 2017).

Wajar jika belakangan ini makin banyak perbankan syariah beregiat islam mengelola reputasinya. Hanya saja, ada beberapa catatan penulis menyikapi fenomena yang terjadi di lapangan. Ada kecendrungan bahwa perbankan syariah melihat reputasi perbankan syariah lebih berdasarkan persepsi internal. Akibatnya, perbankan syariah terjebak dalam perspektif yang menyesatkan. Lantas, bagaimana cara untuk mengetahui seberapa kuat reputasi perbankan syariah.

Dalam hal ini yang dapat dilakukan adalah mengukurnya melalui penelitian pasar. Proses ini dapat menunjukkan di posisi apa reputasi perbankan syariah jika dibandingkan dengan reputasi para pesaing. Selain itu pengukuran reputasi perbedaan 


\section{Jurnal Ilmiah Ekonomi Islam, 7(01), 2021, 504}

syariah juga dapat menunjukkan sektor mana saja yang perlu diprioritaskan secara umum berlaku sebagai road map bagi perjalanan proses pengelolaan reputasi itu sendiriDalam dunia bisnis, risiko bisa muncul akibat adanya ketidakpastian yang biasanya terjadi saat pengambil keputusan tidak memiliki atau hanya memiliki sedikit informasi mengenai apa yang akan diputuskan di masa depan. Bank Islam perlu memiliki berbagai amunisi pengelolaan risiko. Dalam tulisan ini difokuskan kepada Manajemen dalam menghadapi risiko yang mungkin terjadi dalam Pembiayaan Murabahah baik sebelum atau sesudah terjadinya proses pembiayaan murabahah tersebut agar tidak terjadinya atau meminimalisir pencabutan izinusaha pada BPRStersebut.Risiko reputasi menjadi tinggi ketika pelayanan kurang baik. Penerapan prinsip-prinsip Syariah haruslah dilaksanakan secara konsekuen agar tidak timbul penilaian negatif terhadap penerapan sistem Syariah yang dapat mengakibatkan timbulnya publikasi negatif sehingga akan menaikan tingkat risiko reputasi. Kegagalan manajemen risiko reputasi dapat menimbulkan penarikan besar-besaran dana pihak ketiga, menimbulkan masalah likuiditas, ditutupnya Bank oleh otoritas, dan bahkan bisa mengalami kebangkrutan.

Oleh karena itu, tujuan utama manajemen risiko reputasi adalah untuk mengantisipasi dan meminimalkan dampak kerugian dari risiko reputasi Bank Syariah. Risiko reputasi dalam bisnis dapat bersumber dari berbagai aktifitas bisnis Bank Syariah yang meliputi hal-hal misalnya, pemberitahuan negatif di media masa, pelanggaran etika bisnis, dan keluhan nasabah, atau hal-hal lain yang menyebabkan risiko reputasi, misalnya kelemahan-kelemahan pada tata kelola, budaya perusahaan, dan praktik bisnis Bank Syariah. Berdasarkan latar belakang di atas, maka penulis tertarik untuk melakukan Kajian Fiqih Berbasis Margin Murabahah dan Kaitannya Dengan Risiko Reputasi (Studi Kasus diBank Pembiayaan Rakyat Syariah Patriot Bekasi)".

\section{KAJIAN PUSTAKA \\ Devinisi Margin}

Margin adalah persentase tertentu yang ditetapkan perbulan atau pertahun. perhitungan margin keuntungan yaitu suatu istilah yang dipergunakan dalam dunia untuk menunjukkan suatu yang wajib ditempatkan oleh pemegang suatu posisi dalam perdagangan, atau guna melindungi begitu juga dengan lembaga keuangan Syariah, dalam menjalankan bisnis dan usahanya juga tidak terlepas dari sistem Syariah. (Ghozali, 2005)

Margin merupakan selisih antara harga beli dan harga jual, yang merupakan keuntungan kotor dalam transaksi jual beli barang. Margin tidak sama dengan bunga karena margin harus sudah ditentukan pada awal dalam perjanjian dan tidak dapat berubah di tengah jalan. (D. Kasmir, 2006)

\section{Murabahah}

Dalam fatwa Dewan Syariah Nasional (DSN) No. 04/DSN-MUI/IV/2000, pengertian Murabahah yaitu menjual suatu barang dengan menegaskan harga belinya kepada pembeli dan pembeli membayarnya dengan harga yang lebih sebagai laba. (Osmad, 2012)

Pendapat lain tentang definisi Murabahah adalah penjual menyebutkan kepada pembeli harga barang yang ia beli dan ia mensyaratkan keuntungan tertentu berupa uang dinar (emas) atau dirham (perak) kepada pembeli tersebut. (Rusyd, 1990)

Pengertian Bai'al Murabahah adalah jual beli barang pada harga asal dengan tambahan keuntungan yang disepakati. (Arif \& Rianto, 2010)

\section{Murabahah dalam Hukum Islam}

Undang-Undang No. 10 tahun 1998 tentang perbankan dan Fatwa Bunga Bank Haram dari MUI Tahun 2003 menjadi momentum bermunculan banyak Bank yang menjalankan prinsip Syariah. Untuk mengakomodir sengketa perbankan Syariah, maka Undang-undang No.3 tahun 2006 tentang Peradilan Agama menyatakan bahwa sengketa Ekonomi Syariah menjadi kompetensi absolut Peradilan Agama. Sebagai pelengkap, Undang-Undang No. 21 Tahun 2008 tentang perbankan Syariah memberikan payung hukum kepada praktek perbankan Syariah diIndonesia.

\section{Standar Produk Perbankan SyariahMurabahah}

Transaksi murabahah adalah jual beli dengan harga awal ditambah dengan keuntungan tertentu (AlZuhayli, 1997). Secara sederhana, murabahah dapat diartikan dengan jual beli yang dilakukan dengan cara memberitahukan harga belinya kepada pembeli dan pembeli membayarnya dengan harga lebih sebagai keuntungan.

Pada praktek perbankan Syariah, dalam produk murabahah, Bank Syariah membeli barang yang diperlukan nasabah kemudian menjualnya kepada nasabah yang bersangkutan sebesar harga perolehan ditambah dengan margin keuntungan yang disepakati antara Bank Syariah dan nasabah. Yang harus 
diberikan penekanan dalam murabahah adalah penjual harus memberi tahu kepada pembeli harga asli barang tersebut dan berapa besar keuntungan yang akan ia dapatkan. Karena apabila seorang penjual tidak memberi tahu kepada pembeli nlai asli barang tersebut, dan pembayaran dilakukan dengan cara cicilan (lump sum) bukanlah murabahah, akan tetapi disebut musawamah (jual beli mirip murabahah, akan tetapi penjual tidak memberi tahu pembeli berapa jumlah keuntungan yang diambil)

\section{Landasan Hukum Pembiayaan Murabahah}

Murabahah tidak dikenal pada masa Nabi saw. dan sahabatnya, dan mulai muncul pertama kali pada abad kedua Hijriah. Walaupun tidak ada dasar Hadist dan Al-qur" an (karena memang belum dikenal pada masa Nabi) untuk akad ini, akan tetapi Imam Syafiei dan Malik berpendapat bahwa jual beli secara murabahah adalah halal.

Wahbah Zuhaili (dalam Al-Fiqhu wa Adillatuhu) menjelaskan panjang lebar tentang murabahah dan menyatakan bahwa ada beberapa ayat tentang jual beli dan dan perdagangan dalam Al Qur'an yang dapat dijadikan dasar murabahah, seperti Al-baqarah: 275 (...dan Allah menghalalkan jual beli dan mengharamkan riba), dan An-nisa: 29 (Wahai orangorang yang beriman, janganlah kalian makan harta di antara kalian, kecuali dengan cara perdagangan yang berdasarkan atas saling merelakan di antara kalian").

Dia menjelaskan bahwa menurut Imam Malik, ada suatu ijma ${ }^{\text {ee }}$ ulama Madinah tentang kebolehan seseorang yang membeli pakaian di suatu kota dan kemudian menjaulnya di kota yang lain dengan keuntungan yang disepakati. Imam Syafiei juga menyampaikan pendapatnya bahwa jika seseorang mengatakan kepada yang lain, "Belikan suatu barang untukku dan kemudian aku akan memberikan keuntungan kepadamu sekian" adalah diperbolehkan. Marghinani (ulama mazhab Hanafi) juga berpendapat bahwa syarat-syarat pokok dalam jual beli yang dianggap sah terdapat dalam murabahah, dan akad ini sangat diperlukan oleh masyarakat, oleh karena itu akad jual beli murabahah ini adalah boleh. Terakhir, dalam konferensi perbankan Islam ke II (Kuwait, 1403 H/1983) dinyatakan bahwa murabahah hanya diperbolehkan jika pembeli (nasabah) sudah menerima dan memilikibarang.

Di Indonesia, Murabahah telah diperbolehkan (halal) dengan keluarnya Fatwa Dewan Syari'ah Nasional Majelis Ulama Indonesia No: 04/DSNMUI/IV/2000. Dalam fatwa tersebut disebutkan bahwa salah satu alasan dihalalkannya murabahah adalah karena masyarakat banyak memerlukan bantuan penyaluran dana dari Bank syari'ah berdasarkan prinsip jual beli. Masyarakat juga memerlukan bantuan guna melangsungkan dan meningkatkan kesejahteraan diberbagai kegiatan, maka Bank syari'ah perlu memiliki fasilitas murabahah bagi yang memerlukannya.

\section{Dasar Hukum Islam}

Ayat Al-Qur"ean:

An-Nisa [4]: 29

"Hai orang-orang yang beriman, janganlah kamu saling memakan harta sesamamu dengan jalan yang batil, kecuali dengan jalan perniagaan yang berlaku dengan suka samasuka di antara kamu. Dan janganlah kamu membunuh dirimu; sesungguhnya Allah adalah Maha Penyayang kepadamu”. QS. An-Nisa 29

Al-Baqarah [2]: 275

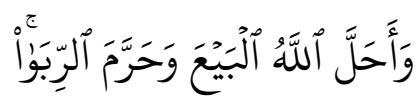

"Padahal Allah telah menghalalkan jual beli dan mengharamkan riba”. (QS. Al-Baqarah [2]: 275)

Dalam ayat ini, Allah SWT mempertegas legalitas dan keabsahan jual beli secara umum serta menolak dan melarang konsep ribawi. Berdasarkan dari ketentuan ini bahwa jual beli Murabahah mendapat pengakuan dan legalitas Syariah, dan sah untuk dijalankan dalam praktek pembiayaan Bank Syariah karena ia merupakan salah satu bentuk jual beli dan tidak mengandung unsur ribawi.Jadi, jual beli yang didalamnya terdapat unsur riba adalah sangat jelas- jelas dilarang oleh AllahSWT.

Sebagaimana yang akan dijelaskan dalam Hadits: (http://akucintakeuangan, 2018:12)

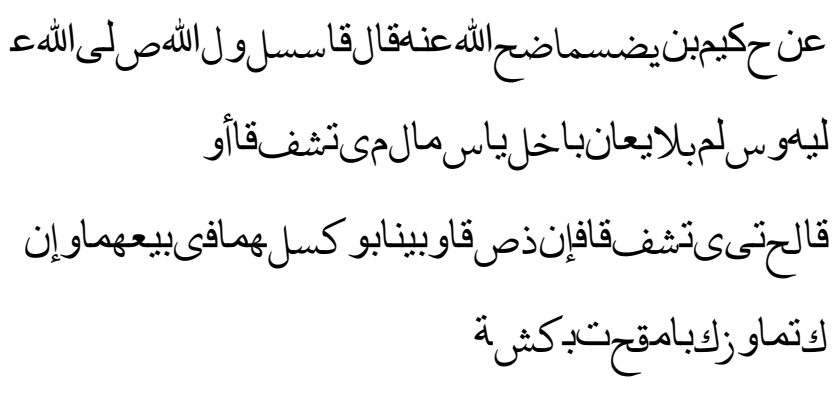

"Dari Hakim bin Hizam berkata ia, bersabda Rasululah SAW"," Dua orang yang berjual beli itu berhak memilih selama keduanya belum berpisah, atau beliau bersabda:" Sehingga keduanya berpisah." Jika keduanya jujur dan 


\section{Jurnal Ilmiah Ekonomi Islam, 7(01), 2021, 506}

terus-terang, maka keduanya mendapat berkah dalam jual-belinya. Jika keduanya menyembunyikan dan berdusta maka dihapuslah berkah jual-belinya itu." (HR. Bukhari)

Begitu pula disebutkan dengan jelas dalam sebuah hadits tentang akad Murabahah seperti yang telah diriwayatkan oleh al-Baihaqi dan Ibnu Majah sebagai berikut:

Artinya: Dari Abu Sa'id Al-Khudri bahwa

RasulullahSAW bersabda, "Sesungguhnya jual beli itu harus dilakukan suka sama suka" (HR. Al-Baihaqi dan Ibnu Majah, dan dinilai shahih (benar) oleh Ibnu Hibban). (Fatwa DSN-MUI, 2017: 3)

Hadits Nabi yang diriwayatkan oleh Ibnu Majah:

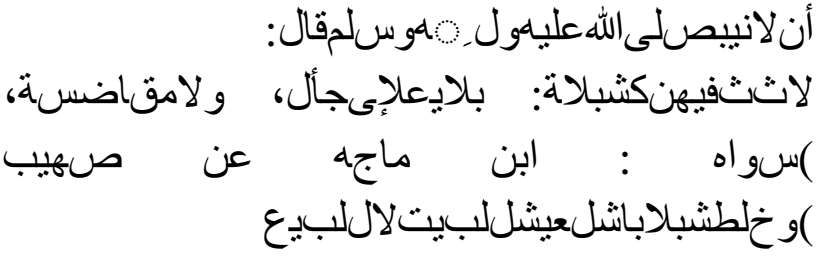

Artinya: "Nabi bersabda, Ada tiga hal yang mengandung berkah: jual beli tidak secara tunai, Muqaradhah (Mudharabah), dan mencampur gandum dengan jewawut untuk keperluan rumah tangga, bukan untuk dijual." (HR. Ibnu Majah dari Shuhaib).

Hadits di atas memberikan prasyarat bahwa akad jual beli Murabahah harus dilakukan dengan suka sama suka, jujur dan terus terang masing-masing pihak ketika melakukantransaksi.

Segala ketentuan yang terdapat dalam jual beli Murabahah, seperti penentuan harga jual, margin yang diinginkan, mekanisme pembayaran, dan lainnya, harus terdapat persetujuan dan kerelaan antara pihak nasabah dan Bank, tidak bisa ditentukan secara sepihak. Mayoritas ulama telah sepakat tentang kebolehan jual beli dengan cara Murabahah sebagai transaksi real yang sangat dianjurkan dan merupakan sunah Rasulullah. Kaidah fiqih tentang Murabahah adalah sebagai berikut: (Sarip, 2015:87)

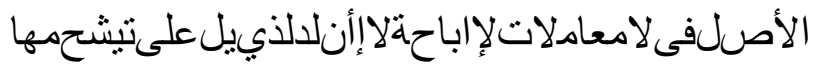

Artinya: "Pada dasarnya, semua bentuk muamalah boleh dilakukan kecuali ada dalil yang mengharamkannya."
Kaidah fiqih tersebut menjelaskan bahwa hukum melaksanakan muamalah yang didalamnya meliputi transaksi Murabahah adalah boleh, kecuali terdapat dalil yang mengharamkan tentang transaksi tersebut.

\section{Standar Produk Perbankan Syariah Murabahah}

Selain memudahkan otoritas dalam proses perizinan dan pengawasan, Standar Produk Murabahah ini diharapkan dapat memberikan pedoman atau referensi standar yang dapat membantu industri dalam pengembangan dan pelaksanaan produk. Buku Standar Produk ini merupakan pelengkap dari Buku Kodifikasi Produk yang telah disampaikan pada tahun lalu kepada industri perbankan Syariah melalui Surat Edaran OJK No.36/SEOJK.03/2015 tentang Produk dan Aktivitas Bank Umum Syariah dan Unit Usaha Syariah sebagai ketentuanlebih lanjut dari Peraturan OJK No.24/POJK.03/2015 tentang Produk dan Aktivitas Bank Syariah dan UUS, yang lebih bersifat penjelasan teknis operasional produk secara lebih rinci dan komprehensif. Dengan demikian, penerbitan Buku Standar Produk ini diharapkan dapat memberikan kepastian hukum dan transparansi produk yang mendukung perlindungan konsumen melalui pemenuhan prinsip Syariah, prinsip kehati-hatian, good governance dan kepatuhan market conduct sehingga dapat meningkatkan daya saing dan pertumbuhan industri perbankan Syariah. (POJK.no5)

\section{Akad Murabahah Dalam Kajian Fiqih}

Pertama, akad murabahah merupakan jenis transaksi yang diperbolehkan dalam syariat. Kedua, unsur pelaku akad ini adalah adanya pemodal dan adanya wakil (orang yang dimodali).

Ketiga, diketahuinya harga beli barang (harga dasar), dan Keempat, adanya perhitungan nisbah rasio keuntungan yang mafhum dan diketahui oleh wakil (orang yang dimodali)

Selanjutnya, Imam al-Mawardi menyebutkan:

Artinya: "Murabahah boleh dilakukan dengan jalan menjumlah pokok harta modal (ra"sul-mâl) sebagai aset, kemudian menjual aset tersebut dengan murabahah. Contoh: Aku (pemodal) beli barang ini seharga 100, dan aku jual ke kamu (pedagang) dengan harga 200 dengan nisbah keuntungan sekian dirham yang ditambahkan. Seolah ia (pemodal) bilang, Aku (pemodal) jual barang ini ke kamu seharga 220. "

Akad ini sama kebolehannya dengan praktik jual beli muhâthah, misalnya ucapan seorang pemodal: 
Aku (pemodal) jual barang ini sesuai dengan harga membelinya, ditambah dengan sekian dirham sebagai tambahan keuntungan." (Lihat: Imam al-Mawardi, alIqna" fi Hillil Alfadh Abi Sujja"e 11468$]$ ) Penjelasan di atas menyebutkan bahwa boleh menetapkan margin keuntungan oleh wakilkepada pihak yang diwakilinya (pedagang). Harga dasar 100, dijual dengan harga 200 ditambah dengan nisbah keuntungan. Melihat proses bagaimana lahirnya akad murabahah ini, beberapa fuqahae mu"ashirah (ahli fiqih kontemporer) menyebut akad ini sebagai akad jual beli atas dasar amanah (,,aqdul buyu 'u al-amânah).

\section{Pengertian Manajemen risiko}

Manajemen Risiko merupakan aktivitas yang utama dari suatu Bank sebagai lembaga intermediasi yang bertujuan untuk mengoptimalkan trade-off antara risiko dan pendapatan, dan untuk membantu merencanakan dan pembiayaan pengembangan usaha secara tepat, efektif, dan efisiensi. Setiap lembaga keuangan, termasuk Bank, harus dapat mengidentifikasi dan mengontrol risiko yang melekat di dalam kegiatan pengelolaan dana simpanan, portofolio aktiva produktif, dan kontrak off balance sheet.

\section{METODE PENELITIAN}

Metode yang digunakan dalam penelitian ini menggunakan metode kualitatif. Lokasi penelitian yang akan diteliti adalah PT. Bank Pembiayaan Rakyat Syariah (BPRS) Patriot Bekasi yang beralamat di jalan Ahmad Yani Komplek Ruko Sentra Niaga Kalimalang Blok C 1 No. 3 Kayuringin Bekasi Selatan. Data yang digunakan dalam penelitian ini adalah data sekunder yang menggunakan Data Ikhtisar Keuangan Kinerja Bank Pembiayaan Rakyat Syariah (BPRS) Patriot Bekasi yang telah diaudit periode 2006-2015. Waktu penelitian dilaksanakan pada bulan Oktober 2019 sampai dengan bulan februari 2020 dan berlangsung selama empat bulan. Objek dalam penelitian ini adalah Pembiayaan Murabahah dan kaitannya dengan risiko reputasi di Bank Pembiayaan Rakyat Syariah (BPRS) Patriot Bekasi. Metode pengumpulan data berupa wawancara, dan observasi. Metode pengolahan data beru[a pemeriksaan data (editing) dan sistematika data (sistematizing). Data akan diolah menggunakan dari permasalahan yang diangkat dalam penelitian ini dengan menggunakan pendekatan deduktif.

\section{HASIL DAN PEMBAHASAN}

3.1. Kajian Fiqih Berbasis Margin Murabahah dan Kaitannya dengan Risiko Reputasi Di Bank Pembiayaan Rakyat Syariah (BPRS) Patriot Bekasi.

PT. BPRS Patriot memiliki permasalah yaitu tentang margin Murabahah karena dalam margin tersebut sudah ditetapkan oleh Otoritas Jasa Keuangan (OJK). Akan tetapi dalam pelaksanaannya terkadang margin tersebut terlalu memberatkan nasabah. Meskipun dalam perbankan Syariah selalu ada kompetitor dalam regulasi margin tersebut. PT. Bank Pembiayaan Rakyat Syariah Patriot Bekasi memiki Dewan Pengawas Syariah yang berkedudukan di PT. Bank Pembiayaan Rakyat Syariah Patriot Bekasi yang selalu mengawasi setiap akad yang berlangsung di lingkungankerjanya.

Ini menjadi pertanyaan besar karena bagaimana pelaksanaan dan implementasi dari margin Murabahah dapat berjalan sesuai aturan yang berlaku, tanpa ada indikasi terhadap unsur yang menyimpang dari Fiqih (Haram, Wajib, Mubah, Makruh dan Sunnah). Tugas yang dilakukan oleh Dewan Pengawas Syariah (DPS) di PT. Bank Pembiayaan Rakyat Syariah Patriot Bekasi khususnya Kantor Cabang PT. Bank Pembiayaan Rakyat Syariah Patriot Bekasi, salah satu

contohnya dalam pembagian waktu saja, karena tidak mungkin Dewan Pengawas Syariah (DPS) dapat setiap waktu ada untuk mengawasi bila di tiap-tiap kantor cabang terjadi penyimpang yang dilakukan.

Dari sinilah Penulis membuat kuesioner kepada nasabah Bank Pembiayaan Rakyat Syariah (BPRS) Patriot Bekasi sebagai berikut:

Tabel 3

Pernyataan mengenai Seberapa Besar Dampak Risiko Terhadap BPRS Patriot Bekasi

\begin{tabular}{|c|c|c|}
\hline $\begin{array}{c}\text { Seberapa Besar Dampak } \\
\text { Risiko Terhadap BPRS } \\
\text { Patriot Bekasi }\end{array}$ & Jumlah & $\begin{array}{c}\text { Persentase } \\
(\%)\end{array}$ \\
\hline Ya & $\mathbf{2 2}$ & $\mathbf{7 2 , 6}$ \\
\hline Tidak & $\mathbf{8}$ & $\mathbf{2 7 , 4}$ \\
\hline Jumlah & $\mathbf{3 0}$ & $\mathbf{1 0 0}$ \\
\hline
\end{tabular}

Sumber: Data Olahan Tahun 2019

Tabel di atas menjelaskan mengenai seberapa besar dampak risiko terhadap BPRS Patriot Bekasi. Hasil penelitian ada 22 responden atau 72,6\% dari 30 respondenMenyatakan ya bahwa dampak risiko sangat besar terhadap BPRS Patriot Bekasi, 
Sedangkan 8 responden atau 27,4\% dari 30 responden yang dijadikan sampel menyatakan tidak, bahwa dampak risiko sangat besar terhadap BPRS Patriot Bekasi. Dengan demikian dapat disimpulkan bahwa dampak risiko sangat besar terhadap BPRS Patriot Bekasi

\section{Tabel 4}

Margin Murabahah yang telah ditentukan dalam Menerapkan Penilaian Aspek Syariah Terhadap Pedoman Operasional dan Produk-Produk Syariah Di BPRS Patriot Bekasi

\begin{tabular}{|c|c|c|}
\hline $\begin{array}{c}\text { Margin Murabahah yang } \\
\text { telah ditentukan dalam } \\
\text { menerapkan penilaian aspek } \\
\text { Syariah terhadap pedoman } \\
\text { operasional dan produk Bank } \\
\text { Pembiayaan Rakyat Syariah } \\
\text { Patriot Bekasi sudah sesuai }\end{array}$ & Jumlah & $\begin{array}{c}\text { Persentase } \\
(\%)\end{array}$ \\
\hline Ya & 26 & $\mathbf{8 6 , 6}$ \\
\hline Tidak & 4 & 13,4 \\
\hline Jumlah & 30 & 100 \\
\hline
\end{tabular}

Sumber: Data Olahan Tahun 2019

Informasi di atas mengenai pelaksanaan peran dalam melakukan penilaian aspek Syariah terhadap pedoman operasionan dan produk-produk Bank Pembiayaan Rakyat Syariah Patriot Bekasi. Hasil penelitiannya adalah dapat diketahui dari 26 respon atau $986,6 \%$ dari 30 responden menyatakan ya, bahwa Dewan Pengawas Syariah (DPS) telah melakukan perannya, yaitu sudah menerapkan penilaian aspek Syariah terhadap pedoman operasional dan produk di Bank Pembiayaan Rakyat Syariah Patriot Bekasi. Sedangkan 4 responden atau 13,4\% dari 30 responden menyatakan tidak, bahwa margin Murabahah telah diterapkan dalam penilaian aspek Syariah terhadap pedoman operasional dan produk di Bank Pembiayaan Rakyat Syariah Patriot Bekasi sudah sesuai.

Dapat disimpulkan bahwa pelaksanaan peran dalam melakukan penilaianvAspek Syariah terhadap pedoman operasional dan produk-produk Bank Pembiayaan Rakyat Syariah Patriot Bekasi sangat baik dan sangat sesuai aturan yang berlaku.
Tabel 5

Peran Bank Pembiayaan Rakyat Syariah (BPRS)

Patriot Bekasi Dalam Memberikan Opini

Mengenai Aspek Kajian Fiqih Terhadap

Pelaksanaan Margin Murabahah terhadap Risiko

Reputasi

\begin{tabular}{|c|c|c|}
\hline $\begin{array}{l}\text { Bank Pembiayaan Rakyat } \\
\text { Syariah (BPRS) Patriot Bekasi } \\
\text { telah menjalankan akad } \\
\text { margin Murabahah secara } \\
\text { konsep Syariah sesuai kajian } \\
\text { Fiqih dengan baik, terbukti } \\
\text { dari opini masyarakat } \\
\text { mengenai aspek Kajian Fiqih } \\
\text { dalam Pelaksanaan Margin } \\
\text { Murabahah terhadap Risiko } \\
\text { Reputasi sudah bisa } \\
\text { diminimalisir }\end{array}$ & Jumlah & $\begin{array}{c}\text { Persentase } \\
(\%)\end{array}$ \\
\hline $\mathbf{Y a}$ & 30 & 100 \\
\hline Tidak & $\mathbf{0}$ & $\mathbf{0}$ \\
\hline Jumlah & 30 & 100 \\
\hline
\end{tabular}

Sumber: Data Olahan Tahun 2019

Tabel di atas terlihat gambaran secara jelas mengenai pelaksanaan peran Bank Pembiayaan Rakyat Syariah (BPRS) Patriot Bekasi dalammenjalankan akad margin Murabahah secara konsep Syariah sesuai kajian Fiqih dengan baik, terbukti dari opini masyarakat sangat mengapresiasi kinerjanya, sehingga dampak terhadap risiko reputasi Bank pun mulaiberkurang.

Ada 30 respon atau100\% dari 30 responden mengatakan bahwa Bank Pembiayaan Rakyat Syariah (BPRS) Patriot Bekasi telah melaksanakan perannya dalam menjalankan akad margin Murabahah secara konsep Syariah sesuai kajian Fiqih dengan baik.

Hasil ini dapat disimpulkan bahwa pelaksanaan peran Bank Pembiayaan Rakyat Syariah (BPRS) Patriot Bekasi telah melaksanakan perannya dalam menjalankan akad margin Murabahah secara konsep Syariah sesuai kajian Fiqih telah dilakukan dengan baik dan optimal. 
Tabel 6

Margin Murabahah tidak mengandung adanya unsur haram dan ribet.

\begin{tabular}{|c|c|c|}
\hline $\begin{array}{c}\text { Penyampaian laporan hasil } \\
\text { yang dilakukan Dewan } \\
\text { Pengawas Syariah (DPS) } \\
\text { BPRS Patriot Bekasi } \\
\text { menyatakan bahwa Margin } \\
\text { Murabahah tidak } \\
\begin{array}{c}\text { mengandung adanya unsur } \\
\text { haram dan ribet yang } \\
\text { memberatkan nasabah }\end{array}\end{array}$ & $\begin{array}{c}\text { Persentase } \\
(\%)\end{array}$ \\
\hline Ya & $\mathbf{2 5}$ & $\mathbf{8 3 , 3}$ \\
\hline Tidak & $\mathbf{5}$ & $\mathbf{1 6 , 7}$ \\
\hline Jumlah & $\mathbf{3 0}$ & $\mathbf{1 0 0}$ \\
\hline
\end{tabular}

Sumber: Data Olahan Tahun 2019

Tabel di atas menjelaskan mengenai pelaksanaan Penyampaian laporan hasil yang dilakukan Dewan Pengawas Syariah (DPS) BPRS Patriot Bekasi menyatakan margin Murabahah tidak mengandung unsur Halal dan Ribet yang memberatkan nasabah.

Diketahui 25 responden atau $83,3 \%$ dari 30 responden yang dijadikan sampel penelitian menyatakan ya, bahwa Dewan Pengawas Syariah (DPS) BPRS Patriot Bekasi telah melaksanakan perannya, yaitu telah menyampaikan laporan hasil yang dilakukan Dewan Pengawas Syaria (DPS) bahwa margin Murabahah tidak mengandung unsur halal dan ribet yang memberatkan nasabah.

Dengan demikian, dari hasil pengamatan di atas dapat disimpulkan secara umum atau sebagian besar responden menyatakan bahwa Margin Murabahah tidak mengandung unsur Gharar, Maysir, pemaksaan dan lain-lain atau yang memberatkan nasabah. Dengan kata lain pelaksanaan peran yang dilakukan oleh Dewan Pengawas Syariah (DPS) di Bank Pembiayaan Rakyat Syariah Patriot Bekasi telah dilakukan dengan baik. Hal ini terbukti 22 hingga 30 responden atau $72,6 \%$ hingga sampai $100 \%$ dari 30 responden menyatakan pelaksanaan peran Dewan Pengawas Syariah di Bank Pembiayaan Rakyat Syariah Patriot Bekasi telah dilakukan dengan baik oleh Dewan Pengawas Syariah (DPS).

Penelitian ini didukung pula dengan hasil wawancara yang dilakukan bersama KH. Ahmad Kusyairi, MA, Ketua Dewan Pengawas Syariah (DPS) di Bank Pembiayaan Rakyat Syariah Patriot Bekasi, "Beliau mengatakan semua produk dan pelaksanaan operasional Bank Pembiayaan Rakyat Syariah Patriot Bekasi telah berjalan dengan konsep dan prinsip
Syariah dengan baik dan selalu diawasi. Bahkan telah mendapat rekomendasi mengacu pada fatwa-fatwa dari Dewan Syariah Nasional (DSN)". (Ahmad Kusyairi, MA, Wawancara).

Dalam hal ini, implementasi dari pelaksanaan peran Dewan Pengawas Syariah (DPS) dalam lembaga keuangan Syariah diharapkan agar lebih mampu melaksanakan pengawasan yang lebih intensif terhadap pelaksanaan operasional dan sistem yang berlaku di sebuah Bank yang menjalani prinsip Syari

Dan bukan itu saja, keberadaan Dewan Pengawas Syariah (DPS) diharapkan menjadi salah satu sumber informasi secara detail mengenai lembaga keuangan tersebut, apakah lembaga keuangan tersebut telah menjalani prinsip perbankan Syariah dengan baik atau masih melanggar perinsip-prinsip perbankan Syariah. Karena itu, akad Murabahah adalah akad yang sangat diminati oleh nasabah dalam bertransaksi karena tidak rumit. Mengenai implementasi pelaksanaan peran Dewan Pengawas Syariah pada Bank Pembiayaan Rakyat Syariah Patriot Bekasi dapat mengawasi, memantau dan memaparkan uraian yang detail mengenai perkembangan produk dan produk Syariah yang sangat dibutuhkan masyarakat untuk menggali informasi lebih dalam lagi mengenai eksistensi lembaga keuangan Syariah jika dibandingkan dengan produk perbankan konvensional saatini.

Dari hasil penelitian yang dilakukan mengenai Kajian Fiqih Berbasis Margin Murabahah dan Kaitannya dengan Risiko Reputasi Di Bank Pembiayaan Rakyat Syariah (BPRS) Patriot Bekasi dapat di lihat pada tabel berikut ini:

Tabel 7

Minimnya pendidikan (edukasi) masyarakat tentang BPRS Patriot Bekasi.

\begin{tabular}{|c|c|c|}
\hline $\begin{array}{c}\text { Apakah minimnya } \\
\text { Pendidikan masyarakat } \\
\text { tentang Bank Pembiayaan } \\
\text { Rakyat Syariah Patriot Bekasi } \\
\text { menjadikan minimnya } \\
\text { informasi, sehingga } \\
\text { menimbulkan berita hoaks } \\
\text { terhadap konsep Syariah } \\
\text { dalam kajian Fiqih pada } \\
\text { margin Murabahah yang } \\
\text { dapat berdampak pada Risiko } \\
\text { Reputasi BPRS Patriot Bekasi }\end{array}$ & Jumlah & $\begin{array}{c}\text { Persentase } \\
(\%)\end{array}$ \\
\hline Ya & 30 & \\
\hline Tidak & $\mathbf{0}$ & $\mathbf{1 0 0}$ \\
\hline Jumlah & $\mathbf{3 0}$ & $\mathbf{1 0 0}$ \\
\hline
\end{tabular}

Sumber: Data Olahan Tahun 2019 
Tabel di atas menginformasikan mengenai minimnya Pendidikan masyarakat tentang Bank Pembiayaan Rakyat Syariah Patriot Bekasi menjadikan minimnya informasi, sehingga menimbulkan berita hoak terhadap konsep Syariah dalam kajian Fiqih pada margin Murabahah yang dapat berdampak pada Risiko Reputasi BPRS Patriot Bekasi.

Ada 30 responden atau $100 \%$ dari 30 responden menyatakan ya, bahwa minimnya Pendidikan masyarakat tentang Bank Pembiayaan Rakyat Syariah Patriot Bekasi menjadikan minimnya informasi, sehingga menimbulkan berita hoak terhadap konsep Syariah dalam kajian Fiqih pada margin Murabahah yang dapat berdampak pada Risiko Reputasi BPRS Patriot Bekasi, sedangkan 0 responden yang menyatakantidak.

Berdasarkan tabel di atas dan uraiannya, maka dapat diambil kesimpulan bahwa minimnya Pendidikan masyarakat tentang Bank Pembiayaan Rakyat Syariah Patriot Bekasi menjadikan minimnya informasi, sehingga menimbulkan berita hoak terhadap konsep Syariah dalam kajian Fiqih pada margin Murabahah yang dapat berdampak pada Risiko Reputasi BPRS PatriotBekasi.

Berdasarkan uraian table di atas dapat disimpulka bahwa, margin murabahah halal karena sudah sesuai dengan DSN-MUI yang berlandaskan Al ${ }^{\text {e Quran dan }}$ Al'Hadits. Tingkat kesesuaian dari kegiatan operasional Bank, penilaian aspek Syariah dalam kajian Fiqih, dan pemberian opini masyarakat terhadap konsep operasional dan produk Syariah berdasarkan fatwa Dewan Syariah Nasioanal (DSN) serta penyampaian laporan hasil pengawasan yang telah dilakukan kepada direksi, komisaris dan Dewan Syariah Nasional (DSN), sehingga margin Murabahah harus sesuai kajian Fiqih yang telah ditetapkan dan mencegah terjadinya risiko reputasi. Hasil penelitian mengenai pelaksanaan tugas yang dilakukan oleh BPRS Patriot Bekasi telah dilakukan dengan baik.

Margin murababah juga murah karena pelaksanaan Kajian Fiqih dalam margin Murabahah dapat dijalankan dengan baik, jangan sampai ada nasabah yang dirugikan dan berdampak pada risiko reputasi BPRS Patriot Bekasi. BPRS Patriot Bekasi yaitu sebagai penasihat dan pemberi saran kepada direksi, pimpinan unit Syariah dan pimpinan Kantor cabang Syariah mengenai hal-hal yang terkait dengan aspek Syariah dan sebagai mediator antara lembaga keuangan Syariah dengan Dewan Syariah Nasional (DSN) juga nasabah. Hasil penelitian yang dilakukan mengatakan bahwa implementasi pelaksanaan dilakukan oleh Bank Pembiayaan Rakyat Syariah (BPRS) Patriot Bekasi dilakukan sangatbaik.

\section{Tabel 8}

Bimbingan, Penyuluhan dan Pelatihan

Dilaksanakan Oleh Bank Pembiayaan Rakyat Syariah (BPRS) Patriot Bekasi Kepada Nasabah

\begin{tabular}{|c|c|c|}
\hline $\begin{array}{c}\text { Apakah Bank Pembiayaan } \\
\text { Rakyat Syariah (BPRS) } \\
\text { Patriot Bekasi melakukan } \\
\text { pembimbingan, penyuluhan } \\
\text { pelatihan kepada nasabah } \\
\text { Bank Pembiayaan Rakyat } \\
\text { Syariah Bekasi untuk } \\
\text { mengklasifikasi konsep } \\
\text { operasional dan produk } \\
\text { Syariah sesuai kajian Fiqih } \\
\text { dan tidak menimbulkan } \\
\text { dampak Risiko Reputasi } \\
\text { terhadap Bank tersebut }\end{array}$ & Jumlah & $\begin{array}{c}\text { Persentase } \\
(\%)\end{array}$ \\
\hline Ya & 29 & 96,7 \\
\hline Tidak & $\mathbf{1}$ & 3,3 \\
\hline Jumlah & 30 & 100 \\
\hline
\end{tabular}

Sumber: Data Olahan Tahun 2019

Tabel di atas menjabarkan dengan jelas mengenai bimbingan, penyuluhan dan pelatihan yang dilakukan oleh Bank Pembiayaan Rakyat Syariah (BPRS) Patriot Bekasi kepada nasabah.

Ada 29 responden atau sebesar $96,7 \%$ dari 30 responden menyatakan ya, bahwa untuk mengklasifikasi konsep operasional dan produk Syariah Bank Pembiayaan Rakyat Syariah (BPRS) Patriot Bekasi melakukan bimbingan, penyuluhan dan pelatihan kepada nasabah Bank Pembiayaan Rakyat Syariah agar nasabah dapat memahami dan mengerti konsep operasional dan produk-produk yang tergolong sesuai Syariah dan tidak melanggar kajian Fiqih dan 1 respoden atau sebesar 3,3\% dari 30 responden menyatakan tidak, bahwa untuk mengklasifikasi konsep operasional dan produk Syariah Bank Pembiayaan Rakyat Syariah (BPRS) Patriot Bekasi tidak melakukan bimbingan, penyuluhan dan pelatihan kepada nasabah Bank Pembiayaan Rakyat Syariah Bekasi.

Maka dari penjelasan di atas dapat diambil kesimpulan bahwa secara umum untuk mengklafikasi konsep operasional dan produk Bank Pembiayaan 
Rakyat Syariah (BPRS) Patriot Bekasi harus melakukan bimbingan, penyuluhan dan pelatihan kepada nasabah Bank Pembiayaan Rakyat Syariah Bekasi agar nasabah dapat memahami dan mengerti konsep operasional dan produk-produk yang tergolong dalam Syariah sesuai dengan kajian Fiqih. Dengan kegiatan itu dapat mencegah terjadinya margin yang tidak sesuai Syariah yang akan merugikan reputasi Bank.

\subsection{Implementasi Margin Murabahah yang sesuai} Fiqih dan tidak berdampak pada Risiko Reputasi Di Bank Pembiayaan Rakyat Syariah (BPRS) PatriotBekasi

Tabel 9

Menganalisa penerapan akad Murabahah di Bank Pembiayaan Rakyat Syariah Patriot Bekasi

\begin{tabular}{|c|c|c|}
\hline $\begin{array}{c}\text { Apakah dalam menganalisa } \\
\text { penerapan akad Murabahah } \\
\text { dapat dilakukan sesuai } \\
\text { dengan kondisi masyarakat } \\
\text { atau nasabah, sehingga } \\
\text { diharapkan tidak terjadinya } \\
\text { wan prestasi atau gagal } \\
\text { bayar }\end{array}$ & Jumlah & $\begin{array}{c}\text { Persentase } \\
(\%)\end{array}$ \\
\hline Ya & $\mathbf{3 0}$ & $\mathbf{1 0 0}$ \\
\hline Tidak & $\mathbf{0}$ & $\mathbf{0}$ \\
\hline Jumlah & $\mathbf{3 0}$ & $\mathbf{1 0 0}$ \\
\hline
\end{tabular}

Sumber: Data Olahan Tahun 2019

Tabel di atas menjelaskan mengenai pelaksanaan menganalisa penerapan akad dapat dilakukan sesuai dengan kondisi masyarakat atau nasabah, sehingga diharapkan tidak terjadinya wan prestasi atau gagal bayar.

Hasil penelitian ada 30 responden atau $100 \%$ dari 30 responden menyatakan ya, bahwa Bank Pembiayaan Rakyat Syariah (BPRS) Patriot Bekasi telah melakukan menganalisa penerapan akad Murabahah dapat dilakukan sesuai dengan kondisi masyarakat atau nasabah, sehingga diharapkan tidak terjadinya wan prestasi atau gagal bayar.

Dengan demikian dapat disimpulkan bahwa secara umum atau sebagian besar telah menganalisa penerapan akad Murabahah dapat dilakukan sesuai dengan kondisi masyarakat atau nasabah, sehingga diharapkan tidak terjadinya wan prestasi atau gagal bayar. Bagaimana untuk mencari solusi dalam penerapan Murabahah yang dinilai belum sempurna. Maka di bawah ini tabelnya.
Tabel 10

Pertanyaan bagaimana untuk mencari solusi dalam penerapan

Murabahah yang dinilai belum sempurna Di BPRs Patriot Bekasi

\begin{tabular}{|c|c|c|}
\hline $\begin{array}{c}\text { Apakah pihak Bank } \\
\text { Pembiayaan Rakyat Syariah } \\
\text { Patriot Bekasi telah mencari } \\
\text { solusi dalam penerapan } \\
\text { Murabahah yang dinilai } \\
\text { belum sempurna yang bisa } \\
\text { menyebabkan pada risiko } \\
\text { reputasi pada nasabah }\end{array}$ & Jumlah & $\begin{array}{c}\text { Persentase } \\
(\%)\end{array}$ \\
\hline Ya & 29 & $\mathbf{9 6 , 7}$ \\
\hline Tidak & 1 & 3,3 \\
\hline Jumlah & 30 & 100 \\
\hline
\end{tabular}

Sumber: Data Olahan Tahun 2019

Dari tabel di atas pihak Bank Pembiayaan Rakyat Syariah Patriot Bekasi telah mencari solusi dalam penerapan Murabahah yang diniulai belum sempurna yang bisa menyebabkan pada risiko reputasi pada nasabah. Ada 29 responden atau 96,7\% dari 30 responden menyatakan ya, bahwa pihak BPRS Patriot Bekasi telah mencari solusi dalam penerapan Murabahah yang dinilai belum sempurna yang bisa menyebabkan pada risiko reputasi pada nasabah.

Sedangkan 1 responden atau 3,3\% dari 30 respondenmenyatakan tidak. Maka dapat disimpulkan bahwa pihak BPRS Pariot Bekasi telah mencari solusi dalam penerapan Murabahah yang dinilai belum sempurna yang bisa menyebabkan pada risiko reputasi pada nasabah telah dilakukan dengan baik.

\section{KESIMPULAN DAN SARAN}

\section{Kesimpulan}

a. Ada 22 responden atau $72,6 \%$ dari 30 responden menyatakan ya bahwa dampak risiko sangat besar terhadap BPRS Patriot Bekasi, sedangkan 8 responden atau $27,4 \%$ dari 30 responden yang dijadikan sampel menyatakan tidak,

b. BPRS Patriot Bekasi telah melaksanakan menganalisa penerapan akad Murabahah dapat dilakukan sesuai dengan kondisi masyarakat atau nasabah, sehingga diharapkan tidak terjadinya wan prestasi atau gagal bayar.

c. Ada 29 responden atau $96,7 \%$ dari 30 responden menyatakan ya, bahwa pihak BPRS Patriot Bekasi telah mencari solusi dalam penerapan Murabahah yang dinilai belum sempurna yang bisa 
Jurnal Ilmiah Ekonomi Islam, 7(01), 2021, 512

menyebabkan risiko reputasi pada nasabah. Sedangkan 1 responden atau $3,3 \%$ dari 30 responden menyatakan tidak. Maka dapat disimpulkan bahwa pihak BPRS Patriot Bekasitelah mencari solusi dalam penerapan Murabahah yang dinilai belum sempurna yang bisa menyebabkan pada risiko reputasi pada nasabah. telah dil;akukan dengan baik.

\section{Saran}

a. Diharapkan dampak risiko yang sangat besar terhadap BPRS Patriot Bekasi, dapat berkurang dengan adanya evaluasi secara berkala. Juga adanya pengawasan yang ketat dalam pemberian pembiayaan Murabahah kepada nasabah agar meminimalisir gagal bayar yang terjadi.

b. BPRS Patriot Bekasi harus melaksanakan penganalisaan dalam penerapan akad Murabahah secara periodik, sehingga dapat dilakukan sesuai dengan kondisi masyarakat atau nasabah dan diharapkan tidak terjadinya wan prestasi atau gagal bayar dikemudian hari.

c. Pihak BPRS Patriot Bekasi harus mencari solusi dalam penerapan akad Murabahah yang dinilai belum sempurna yang bisa menyebabkan pada risikoreputasi pada nasabah.

\section{REFERENSI}

Al-Zuhayli, W. (1997). al-Fiqh al-Islami waAdillatuh. Dar al-Fikr.

Arif, N. R., \& Rianto, M. N. (2010). Dasar-Dasar Pemasaran Bank Syariah. Bandung: Alfabeta.
Fauziah, S. (2019). Manajemen Risiko Reputasi pada Perbankan Syariah Di Indonesia. EKSISBANK: Ekonomi Syariah Dan Bisnis Perbankan, 3(1), 74-80.

Ghozali, A. (2005). Saham Syariah. Retrieved from Web Site Republika Tentang Pasar Modal: www. webmaster. com.

Hasan, Z. (2009). Undang-Undang Perbankan Syariah: Titik Temu Hukum Islam dan Hukum Nasional. Rajawali Pers.

Kasmir, D. (2006). Kewirausahaan. Raja Grafindo Persada. Jakarta, Indonesia.

Kasmir, S. (2014). Bank dan Lembaga Keuangan Lainnya. Edisi Revisi.

Lubis, A. (2016). APLIKASI MURABAHAH DALAM PERBANKAN SYARIAH. FITRAH: Jurnal Kajian Ilmu-Ilmu Keislaman, 2(2), 181202.

Osmad, M. (2012). Akuntansi Perbankan Syariah. Yogyakarta: Graha Ilmu.

Rusyd, I. (1990). Bidayatul Mujtahid wa Nihayah alMuqtashid. Editor: Ahmad Abu Al Majd, Darul Aqidah-Kairo, Cet. I, 1425.

\section{Peraturan Perundangan}

Majelis Ulama Indonesian, Keputusan DSN MUI, No. Kep-98/MUI/III/2001 Tentang Susunan Pengurus DSN-MUI Bagian Peran DPS

Undang-Undang Republik Indonesia Nomor 40 Tahun 2007 Tentang Perseroan Terbatas, LNRI Tahun 2007 Nomor :106. 